\title{
MHEALTH UNTUK KEPATUHAN PASIEN TB DALAM PENGOBATAN: SEBUAH TINJAUAN LITERATUR
}

\section{MHEALTH FOR ADHERANCE TB PATIENTS IN TREATMENT: A LITERATURE REVIEW}

\author{
Novi Pampalia ${ }^{1}$ \\ Agung Waluyo ${ }^{2}$ \\ ${ }^{1}$ Mahasiswa Magister Fakultas Ilmu Keperawatan, Universitas Indonesia, Depok Indonesia \\ ${ }^{2}$ Departemen Penyakit Dalam, Fakultas Ilmu Keperawatan Universitas Indonesia, Depok 16424, Indonesia \\ e-mailnovi_istiqomah@yahoo.com
}

\begin{abstract}
ABSTRAK
Tuberkulosis (TB) merupakan masalah kesehatan yang menjadi perhatian dunia. Indonesia menduduki peringkat nomor 3 tertinggi di dunia. Mobile phone merupakan teknologi yang sudah tidak asing lagi bagi berbagai kalangan usia. Mobile phone yang digunakan untuk kesehatan dikenal sebagai mHealth. Manfaat mHealth dapat digunakan dalam mengatasi faktor yang menyebabkan rendahnya kepatuhan pengobatan. Metode:Pencarian artikel yang relevan telah dilakukan dengan menggunakan kata kunci " $m$ Health for TB" AND " $m$ Health for Adherance TB". Pencarian literatur dengan menggunakan mesin pencarian online Sciencedirect, EBSCO, Proquest, google scholar dari tahun 2013-2019. Hasil:Penggunaan mHealth terdiri dari sms otomatis, panggilan telfon, dan video edukasi. Pemanfaatan dari berbagai jenis $m$ Health ini digunakan sesuai dengan kebutuhan dari pasien. Manfaat mHealth sms otomatis dan telfon yaitu sebagai pengingat minum obat dan jadwal kunjungan rutin. Video edukasi memberikan informasi mengenai TB dan motivasi dari kelompok sebaya. Kesimpulan: Penggunaan teknologi mHealthdapat meningkatkan kepatuhan pasien TB dalam pengobatan dengan metode pengingat minum obat, jadwal kunjungan rutin, edukasi, dan dukungan sosial. Rekomendasi: Beberapa manfaat penggunaan $m$ Health telah dibuktikan oleh beberapa studi di luar negeri. Untuk itu diperlukan studi lebih lanjut tentang intervensi pelayanan kesehatan seperti DOTS pada pasien TB menggunakan aplikasi $m$ Health di Indonesia.
\end{abstract}

Kata kunci: Edukasi, mHealth; Kepatuhan; TB

\section{ABSTRACT}

Backgroun: Tuberculosis (TB) is a health problem of global concern. Indonesia is ranked number 3 in the world. mobile phone is a technology that is familiar to various age groups. The mobile phone used for health is known as mHealth. The benefits of mHealth can be used in overcoming factors that cause low medication adherence. Method: Search for relevant articles was carried out using the keywords " $m$ Health for TB" AND "mHealth for Adherance TB". Searching of literature was using online search engines namely Sciencedirect, EBSCO, Proquest, google scholar from 2013-2019. Results: MHealth is used for TB treatment including automatic sms, telephone calls, and educational videos. Utilization of various types of mHealth is used according to patient needs. The benefits of mHealth automatic sms and telephone are as a reminder to take medication and schedule regular visits. Educational videos provide information about TB and motivations from peer groups. Conclusion: The use of mHealth technology can improve TB patient compliance in treatment with medication reminder methods, regular visit schedules, education, and social support. Recommendations: Some of the benefits of using mHealth have been proven by several studies. For this reason, further studies are needed on health service interventions such as DOTS in TB patients using the mHealth application in Indonesia.

Keywords:Adherence; $m$ Health; Education; TB 


\section{PENDAHULUAN}

Tuberkulosis (TB) merupakan masalah kesehatan yang menjadi perhatian dunia. Pada tahun 2030 ditargetkan pengurangan $90 \%$ kematian TB dan $80 \%$ penurunan angka kejadian TB dibandingkan dengantahun 2015. Sedangkan target paling dekat pada tahun 2020 adalah pengurangan $35 \%$ kematian $\mathrm{TB}$ dan $20 \%$ penurunan angka kejadian TB dibandingkan tahun $2015^{1}$. Angka kejadian TB dunia ada sekitar 10 juta jiwa dimana penyandang TB terbesar berada di wilayah Asia Tenggara yaitu 4,44 juta jiwa. Posisi Indonesia berada di urutan ketiga dunia setelah India dan Cina.Selain itu Indonesia termasuk 10 besar high-burden country untuk TB, TB/HIV dan MDR TB ${ }^{1}$.

Berbagai program telah dicanangkan dunia yaitu directly observed treatment short course (DOTS) untuk pasien TB. DOTS adalah strategi yang direkomendasikan secara internasional untuk pengendalian TB yang telah diakui sebagai strategi yang sangat efisien dan hemat biaya ${ }^{2}$. Pengobatan pasien TB berlangsung lama, yaitu 6 bulan $^{3}$. Proses pengobatan yang lama menyebabkan pasien cenderung bosan dan memungkinkan mengalami penurunan motivasi untuk berobat. Ketidakpatuhan akan pengobatan akan menyebabkan TB sulit disembuhkan bahkan berisiko menjadi TB Kebal Obat. Banyak kasus TB berkembang menjadi TB Kebal Obat sehingga membuat pengobatan semakin sulit. Salah satu penyebab TB Kebal Obat adalah tingkat kepatuhan pengobatan pasien TB masih rendah.

Menurut sebuah studi beberapa alasan pasien tidak patuh adalah makanan yang tidak adekuat, rendahnya komunikasi antara penyedia pelayanan kesehatan dan pasien, adanya kepercayaan pada sistem penyembuhan tradisional, ketidaksediaan fasilitas layanan yang dekat, efek samping, dan stigma serta diskriminasi ${ }^{4}$. Beberapa faktor-faktor diatas diintervensi dengan penggunaan mHealth diantaranya adalah tingkat pengetahuan yang masih rendah, faktor kelupaan minum obat, membutuhkan informasi yang segera misal saat muncul efek samping pengobatan, serta stigma.

Mobile Phone merupakan teknologi saat ini yang sudah tidak asing lagi bagi berbagai macam usia. Pada dunia kesehatan penggunaan teknologi seluler dikenal dengan mHealth. Berbagai studi diluar negeri memaparkan manfaat penggunaan mHealth pada pasien TB. Namun di Indonesia belum ada studi tentang penggunaan Mobile Phone terhadap kepatuhan pasien TB. Untuk itu diperlukan studi literatur tentang manfaat penggunaan mHealth untuk pasien TB. Studi literatur ini bertujuan untuk menggambarkan pengunaan dan manfaat mHealthuntuk kepatuhan pasien TB pada pengobatan yang terdiri dari kepatuhan minum obat dan evaluasi pengobatan

\section{METODE}

Kriteria: literatur ini memasukkan berbagai jenis penelitian termasuk kuantitatif dan kualitatif untuk menggambarkan manfaat mHealth untuk kepatuhan pada pasien TB. Startegi pencarian literature: untuk mencari artikel yang relevan maka pencarian dilakukan dengan menggunakan kata kunci " $m$ Health for TB" AND “MHealth for Adherance TB".

Seleksi artikel: pencarian literatur dengan menggunakan online database yaitu Sciencedirect, EBSCO, Proquest, google scholar dari tahun 2013-2019. Artikel relevan yang dipilih menggunakan bahasa inggris dan fulltext. Setelah menghapus artikel serupa atau duplika, artikelterkait diambil. 


\section{HASIL}

Beberapa hasil dari penelusuran literatur diuraikan dibawah ini, mHealth yang ditemukan seperti SMS, panggilan telp dan videografi.

\section{SMS}

Suatu studi dilakukan di Lesotho untuk melihat manfaat pemberian pesan otomatis dari server kepada pasien TB/ $\mathrm{HIV}^{5}$. Sistem kerja dari mHealth pada studi ini adalah tenaga kesehatan yang sudah dilatih memasukkan data ke server kemudian server mengirimkan sms yang diteruskan ke pasien. Isi dari pesan singkat ini diantaranya pengingat untuk kontrol ke klinik dan pengingat minum obat secara tepat waktu. Waktu minum obat disepakati antar pelayanan kesehatan dengan pasien. Pesan singkat minum obat tidak secara langsung mengatakan minum obat TB maupun ART tetapi diberikan dengan kode "sudahkah anda makan sekarang?"5.

Mayoritas pasien mengatakan sms pengingat ini sangat bermanfaat sebagai salah satu hal yang penting untuk mendukung kepatuhan pengobatan TB. Manfaaat pesan singkat ini dirasakan pasien membuat mereka merasa dihargai dan diperhatikan. Sehingga hasil akhir dari studi ini menyebutkan pasien maupun tenaga kesehatan menyatakan kepatuhan pasien dalam minum obat meningkat serta kontrol evaluasi pengobatan meningkat ${ }^{5}$.

\section{Panggilan Telp}

Sebuah studi cross-sectional di India mengeksplor penggunan komunikasi via mobile phone untuk terapi TB pada 150 pasien yang diambil acak pada lima lokasi yang berbeda. Dari hasil studi ini didapatkan sebagian besar pasien dan tenaga kesehatan melakukan komunikasi melalui mobile phone. Komunikasi ini dilakukan oleh tenaga kesehatan yang menelpon pasien maupun sebaliknya ${ }^{6}$.

$$
\begin{array}{lrrr}
\text { Pada } & \text { studi ini disebutkan } & \text { petugas } \\
\text { kesehatan } & \text { menggunakan ponsel } & \text { untuk }
\end{array}
$$

menghubungi pasien sebagai pemberitahuan harian tentang minum obat, serta dapat mendeteksi dan melaporkan efek samping pengobatan. Komunikasi ini sangat penting sebagai pengingat pasien minum obat, karena beberapa pasien tidak pandai menggunakan vitur ponsel seperti alarm ataupun reminder ${ }^{6}$.

Studi lain dilakukakan di Kamboja tahun 2017 terhadap pasien TB yang dirujuk, studi ini mengkaji panggilan telpon untuk memastikan pasien TB yang dirujuk mendapatkan pengobatan $\mathrm{TB}$ sesuai standar dan tercatat tanggal mulai terapi. Hasil penelitian menunjukkan $97 \%$ pasien dapat dihubungin secara langsung, sedangkan $3 \%$ lainnya dihubungi melalui pelayanan kesehatan yang dirujuk. Total 99\% pasien yang sudah rujuk dalam pengobatan TB sudah ditindaklanjuti sesuai dengan standar pengobatan $\mathrm{TB}^{7}$.

\section{VDOT (Video DOT)}

Studi yang dilakukan di Amerika dilakukan penelitian untuk penggunaan VDOT pada dua wilayah dengan high-and low-resource Settings (California dan Mexico). Setting penelitian yaitu pasien merekam dan mengirimkan konsumsi obat melalui video untuk diawasi dari jauh oleh penyedia layanan kesehatan dan dilakukan dokumentasi kepatuhan minum obat $^{8}$. Menurut studi ini penggunaan VDOT bermanfaat untuk memudahkan pengawasan minum obat bagi pasien yang tidak bisa dilakukan pengawasan secara langsun. Kelebihannya adalah menghemat biaya transportasi dan dapat membantu bagi pasien yang tidak punya pengawas minum obat (PMO) secara individu.

\section{Video Edukasi Keluarga}

Sebuah studi di Elsavador menunjukkan bagaimana efektifitas penggunaan video edukasi keluarga dalam peningkatan pemahaman dan kepatuhan pasien dan keluarga tentang TB. Studi 
ini memaparkan video 7 menit tentang: (1) informasi dasar tentang apa itu TB dan bagaimana didapatnya, (2) poin mendasar bagaimana TB terdeteksi dan berhasil diobati, (3) kesalahpahaman masyarakat tentang TB dan (4) testimoni pasien mengenai pengalaman mereka dengan TB dan pengobatannya. Video berisi tentang penjelasan secara verbal oleh penyedia layanan dan pasien yang dinyatakan sembuh yang di paparkan dengan grafik dan gambar serta teks narasi untuk memperkuat poin-poin konten video ${ }^{9}$.

Setelah melihat video, pasien mengungkapkan pemahaman yang lebih besar tentang TB termasuk bagaimana TB dapat ditularkan dan berhasil diobati, serta pandangan diagnosis yang lebih optimis. Anggota keluarga yang menonton video tersebut juga memperlihatkan lebih sedikit rasa takut dan minat yang lebih besar terhadap TB dan juga menunjukkan lebih banyak dukungan untuk kerabat yang sedang menjalani pengobatan. Penyedia kesehatan TB Elsalvador melaporkan peningkatan kepatuhan pasien terhadap pengobatan, penyelidikan pasien yang suspek $\mathrm{TB}$, pengiriman sampel dahak untuk pengujian, efisiensi waktu klinik yang dihabiskan bersama pasien, dan pengurangan stigma keluarga TB pada kerabatnya ${ }^{9}$.

\section{PEMBAHASAN}

Berbagai macam jenis dari mHealth diantaranya sms otomatis, voice call sebagai pengingat minum obat, pengingat untuk kontrol rutin, serta mengingatkan jadwal pemeriksaan laboratorium untuk evaluasi pengobatan TB. Sebuah studi di Ethiopia tentang faktor yang menyebabkan ketidakpatuhan terhadap pengobatan diantaranya karena pelupa (34\%), efek samping muntah (24\%), sedangkan alasan lainnya karena berpergian $(17 \%)^{1}$. Pengingat dari teknologi mHealth menjadi salah satu alternatif yang bisa ditawarkan untuk perawatan pasien dan sebagai salah satu sistem pendukung ${ }^{3}$.

Sebuah studi di India Selatan tentang penggunaan mHealth untuk manajemen TB, menyebutkan bahwa 151 responden dari 185 memakai smatphone ${ }^{10}$. Tingginya pemakaian smartphone merupakan peluang dibidang kesehatan. Misal memanfaatkan mHealth untuk kepatuhan dan sebagai dukungan untuk pasien dalam menjalani pengobatan. Selanjutnya studi ini menyebutkan mayoritas responden $(98,4 \%)$ membutuhkan informasi kesehatan melalui telepon. Informasi tersebut diantaranya pesan tentang kemajuan dalam pengobatan TB, informasi tentang obat-obat, pengingat minum obat dan pesan memotivasi kesehatan ${ }^{10}$.

Salah satu kebutuhan pasien adalah konunikasi dengan tenaga kesehatan untuk mendapatkan informasi. Salah satu manfaatmHealth ketika seseorang jauh dari pelayanan kesehatan. Selain sebagai pengingat teknologi mHealth menjadi salahsatu solusi untuk pasien mendapatkan informasi baik dari video edukasi maupun konsultasi melalui telpon ketika mendapatkan efek samping atau membutuhkan infromasi lainnya. Dampak yang diperoleh yaitu dapat menghemat waktu serta finansial untuk datang ke pelayanan kesehatan. mHealth dapat menurunkan stigma sosial karena komunikasi dapat melalui telepon, sehingga pasien tidak perlu mendatangi klinik khusus TB untuk keperluan yang dapat diselesaikan dengan telepon.

\section{SMS}

Penggunaan mHealth yang mudah digunakan dan murah adalah SMS otomatis. Keuntungan SMS otomatis ini dapat diatur tentang isi pesan yang akan dikirimkan maupun waktu yang telah disepakati bersama ${ }^{5}$. Misalnya untuk mengingat minum obat ataupun pengingat waktu kontrol. 
Sejalan dengan hal tersebut penggunaan mHealth melalui SMS juga dilakukan pada pasien HIV di Zimbabwe. Studi ini memaparkan tentang manfaat pemberian informasi hasil viral load HIV melalui SMS ${ }^{12}$. Pemberian informasi hasil melalui sms ini membuat responden tidak perlu harus datang lagi ke RS maupun klinik.Namun studi tentang penggunaan SMS pengingat minum obat untuk pasien $\mathrm{TB}$ di Pakistan menunjukkan bahwa tidak ada perbedaan signifikan antara partisipan yang diberi SMS pengingat dengan yang tidak diberi $\mathrm{SMS}^{7}$

Penggunaan SMS memiliki beberapa kelemahan. Sebagai contoh, tidak semua pasien memahami isi pesan sms yang dikirim. Hal ini berkaitan dengan tingkat pemahaman pasien berdasarkan latar belakang pendidikan dan bahasa keseharian yang digunakan. Sejalan dengan penelitian dari India, responden yang berusia muda, pekerja, dan serta memiliki pendidikan yang tinggi lebih mungkin menggunakan SMS untuk menerima informasi maupun pengingat minum obat melalui $\mathrm{SMS}^{10}$. Kelemahan lainnya memungkinkan kecenderungan pasien untuk mengabaikan pesan sms yang diterima dikarenakan tingkat kejenuhan yang dialami akibat menerima sms yang sama setiap hari.

Penggunaan SMS otomatis sebagai salah satu sarana mHealth untuk kepatuhan pasien dalam pengobatan tetap dapat menjadi alternatif pilihan. Untuk meyakinkan efektif dan efisien terhadap kepatuhan minum obat, perlu dilakukan monitoring berkala melalui panggilan telpon atau saat kunjungan ke poli TB mengenai tingkat atensi pasien terhadap SMS yang diterima.

\section{Panggilan Telepon}

Selain dari SMS, penggunaan mHealth dengan panggilan telepon. Komunikasi melalui panggilan telepon sangat penting sebagai pengingat pasien minum obat, dan sebagai alternatif untuk pasien yang tidak pandai menggunakan fitur HP lainnya seperti alarm pengingat $^{6}$. Panggilan telepon dapat digunakan untuk memastikan keberlangsungan pengobatan pasien TB yang telah dirujuk ke fasilitas kesehatan lanjut ${ }^{2}$. Manfaat anggilan telepon ini untuk kepastian pencatatan dan pelaporan yang tepat.

\section{Video}

Video edukasi pasien TB ditonton bersama keluarga di fasilitas kesehatan.Manfaat keterlibatan keluarga ini dapat meningkatkan bounding dengan anggota keluarga yang menderita sakit $\mathrm{TB}^{9}$. Stigma pada pasien TB dapat terjadi baik pasien yang menstigma diri, maupun di dapat dari stigma sosial, begitu juga dengan stigma sosial yang akan dihadapi oleh keluarga pasien. Pengetahuan yang didapat dari video akan membuat pasien dan keluarga memahami TB dan menjadi dukungan yang akan membuat pasien dan keluarga semangat dalam berobat dan menyelesaikan pengobatan.

Studi lain menjelaskan tentang manfaat video melalui program Photovoice. Program ini adalah video yang berisi pasien TB yang sudah sembuh berbagi pengalaman tentang pengobatan TB. Studi ini membandingkan kepatuhan pengobatan dan hasil pengobatan OAT (obat anti tuberculosis) diantara pasien yang terpajan video dan pasien yang tidak terpajan. Hasilnya adalah 135 pasien yang menonton video memiliki peluang sukses pengobatan 3 kali lebih besar dibandingkan dengan yang tidak menonton ${ }^{14}$. Menonton video pasien yang sudah sembuh memberikan motivasi diri bagi pasien yang baru terdiagnosa TB, kepercayaan pasien terhadap kesembuhan pengobatan TB akan meningkatkan kepatuhan pengobatan. 


\section{SIMPULAN}

Pengobatan TB yang lama membuat pasien berisiko putus berobat dengan berbagai penyebab yang melatarbelakangi putus berobat. Penggunaan teknologi mHealth dapat menjadi salah satu alternatif untuk meningkatkan kepatuhan pasien TB dalam pengobatan dengan metode pengingat minum obat, jadwal kunjungan rutin, edukasi, dan dukungan sosial.

\section{REKOMENDASI}

Perlu studi yang lebih lanjut tentang intervensi pelayanan kesehatan seperti DOT pada pasien TB dengan menggunakan aplikasi mHealth di Indonesia. Sehingga pelayanan dimasa yang akan datang memungkinkan ada aplikasi tentang pelayanan TB untuk pasien yang berisi tentang informasi dan sistem pelayanan yang dapat meningkatkan kepatuhan pasien TB. Pemerintah dari pusat sampai ke pelayanan lini depan yaitu poli DOTS baik dari rumah sakit, puskesmas maupun layanan praktek swasta menggunakan aplikasi kepatuhan TB untuk pasien yang ditautkan langsung dengan data laporan pusat kesehatan misal subdit TB Kemenkes.

\section{DAFTAR PUSTAKA}

1. World Health Organization. Global Tuberculosis Report 2018. Geneva: WHO; 2018. URL: $\quad$ https://www.who. int/tb/publications/global_report/en/

2. World Health Organization. What is DOTS (Directly Observed Treatment, Short Course). WHO; 2019. URL: http:/www.searo.who.int/tb/topics/what do $\underline{\text { ts/en/ }}$

3. World Health Organization. Guidelines for treatment of drug-susceptible tuberculosis and patient care, 2017 Update. Geneva: WHO; 2017. ISBN 978-92-4-155000-0

4. Gugssa C, Shimels T, Bilal AI. Factors contributing to non-adherence with treatment among TB patients in Sodo
Woreda, Gurage Zone, Southern Ethiopia : A qualitative study. Journal of Infection and Public Health 2017; 10 (5): 527-533. https://doi.org/10.1016/ j.jiph.2016.11.018

5. Hirsch-Moverman Y, Daftary A, Yuengling KA, Saito S, Ntoane M, Fredix K, et al. Using mHealth for HIV/TB treatment support in Lesotho: enhancing patientprovider communication in the START study. Journal of Acquired Immune Deficiency Syndromes 2017 Jan 1; 74: S37S43.https://doi.org/10.1097/QAI.000000000 0001202

6. Elangovan R, ArulchelvanS. A study on the role of mobile phone communication in tuberculosis dots treatment. Indian Journal of Community Medicine 2013 Oct; 38 (4): 229-233. $\quad$ https://doi.org/10. 4103/09700218.120158

7. Choun K, Achanta S, Naik B, Tripathy JP, Thai S, Lorent $\mathrm{N}$, et al. Using mobile phones to ensure that referred tuberculosis patients reach their treatment facilities: a call that makes a difference. BMC Health Services Research 2017 Aug 22, 17 (1): 575. https://doi.org/10.1186/s12913-0172511-X

8. Garfein RS, Collins K, Moser K, Raab F, Rios P, Flick A, et al. Feasibility of tuberculosis treatment monitoring by video directly observed therapy : a binational pilot study. 2015;19(April):1057-64.

9. Wilson JW, Ramos JG, Castillo F, Castellanos EF, \& Escalante P. Tuberculosis patient and family education through videography in El Salvador. Journal of Clinical Tuberculosis and Other Mycobacterial Diseases 2016; 4:14-20. https://doi. org/10.1016/j.jctube.2016.05.00

10. Kumar AA, De Costa A, Das A, Srinivasa GA, D'Souza G, Rodrigues R. Mobile Health for Tuberculosis Management in South India: Is Video-Based Directly 
Observed Treatment an Accepable Alternative?. JMIR MHealth Uhealth 2019; 7 (4): e11687. https://doi.org/10.2196/11687

11. Hirsch-Moverman Y, Daftary A, Yuengling KA, Saito S, Ntoane M, Fredix K, et al. Using mHealth for HIV/TB treatment support in Lesotho: enhancing patientprovider communication in the START study. Journal of Acquired Immune Deficiency Syndromes 2017 Jan 1; 74: S37S43.https://doi.org/10.1097/QAI.000000000 0001202

12. Venables E, Ndlovu Z, Munyaradzi D, Mart1'nez-Pe'rez G, Mbofana E, Nyika P, et al. Patient and health-care worker experiences of an HIV viral load intervention using SMS: A qualitative study. PLoS ONE 2019; 14(4): e0215 236. https://doi.org/ $10.1371 \quad$ /journal .pone. 0215236

13. Mohammed S, Glennerster R, Khan AJ. Impact of a Daily SMS Medication Reminder System on Tuberculosis Treatment Outcomes: A Randomized Controlled Trial. PLoS One 2016; 11 (11): e0162944. $\quad$ https://doi.org/10. 7910/DVN/HVJ2CM.Funding

14. Shelke SC, Adhave PS, Moonan PK, Willis M, Parande MA, Satyanarayana S, et al. Photovoice: A Novel Approach to Improving Antituberculosis Treatment Adherence in Pune, India. Tuberculosis Research \& Treatment 2014; 302601. https://doi.org/10.1155/2014/302601 